Chirurgia (2019) 114: 564-570

No. 5, September - October

Copyright $\subset$ Celsius

http://dx.doi.org/10.21614/chirurgia.114.5.564

\title{
Post-thyroidectomy Hypocalcemia - Risk Factors and Management
}

\author{
Dan Nicolae Păduraru' ${ }^{1,2}$, Daniel Ion ${ }^{1,2}$, Mara Carsote ${ }^{1,3}$, Octavian Andronic $^{1,2}$, Alexandra Bolocan ${ }^{1,2}$ \\ 'The University of Medicine and Pharmacy Carol Davila Bucharest, Romania \\ Emergency University Hospital of Bucharest, Romania \\ ${ }^{3}$ C.I. Parhon National Institute of Endocrinology, Bucharest, Romania
}

Corresponding author:

Octavian Andronic, MD

The University of Medicine and

Pharmacy Carol Davila Bucharest,

Romania

E-mail: andronicoctavian@gmail.com

Abbreviations:

g - Grams;

MEN - Multiple Endocrine Neoplasia;

PTH - Parathormone.

\section{Rezumat}

Hipocalcemia post-tireidectomie - factori de risc și management

Complicațiile tiroidectomiei variază de la hipocalcemie şi leziuni recurente ale nervului laringian la lezarea pliurilor vocale, hematom local, chisturi, granulom. Hipocalcemia postoperatorie are o incidență de 1,2-40\%. Hioparatiroidismul permanent este înregistrat în $3 \%$ din cazuri. Articolul de față este review de tip narativ care se concentrează asupra nivelului de calciu după efectuarea unei tiroidectomii şi a necesității administrării suplimentelor de calciu în aceste condiții. Această complicație, chiar dacă pare mai degrabă inofensivă la început, reprezintă de fapt un element important la întârzierea spitalizării şi, mai ales la formele severe, la calitatea scăzută a vieții, inclusiv la apariția de episoade cu risc vital. Devascularizarea glandelor paratiroide, pe lângă lezare sau disecție, provoacă hipoparatiroidism. Riscul de hipocalcemie diferă în funcție de sex (femeile au un risc mai mare), disecția ganglionilor limfatici (creşte riscul), diferă în funcție de tipul tiroidectomiei (disecțile mai mari au un risc mai mare; de asemenea, intervenția pentru guşă recurentă şi reintervenția pentru sângerare post-operatorie cresc riscul de hipocalcemie; în timp ce boala Basedow este probabil cu un risc mai mare decât guşa multinodular, dintre afecțiunile benigne) şi durata procedurii. Rata de scădere a calciului contează şi ea: o scădere de $1 \mathrm{mg} / \mathrm{dL}$ în 12 ore post-operație este corelată independent cu riscul de hipocalcemie simptomatică. PTH precoce postoperator şi calciul sunt cei mai buni predictori pentru necesitatea suplimentelor orale de calciu. Suplimentarea de rutină postoperatorie de calciu şi vitamina D semnificativă din punct de vedere statistic scade riscul de a 
dezvolta hipocalcemie tranzitorie şi complicații acute în comparație cu suplimente de calciu singur sau fără suplimente. În cazurile de hipoparatiroidism este preferat calcitriolul.

Key words: thyroidectomy, thyroid, calcium, hypoparathyroidism

\begin{abstract}
The complications of thyroidectomy vary from hypocalcemia and recurrent laryngeal nerve lesions to injury of vocal folds, local hematoma, cysts, granuloma. Post-operative hypocalcemia has an incidence of $1.2-40 \%$. Permanent hyoparathyroidism is registered in $3 \%$ of cases. This is a brief narrative review focusing on the levels of calcium after performing a thyroidectomy and the need of calcium supplements under these circumstances. This complication, even it seems rather harmless at first, in fact it represents an important contributor to hospitalization delay and, especially for severe forms, to poor quality of life, including the risk of life threatening episodes. Devascularisation of parathyroid glands in addition to injury or dissection causes hypoparathyroidism. Hypocalcemia risk differs with sex (females have a higher risk), lymph node dissection (it increases the risk), it differs with type of thyroidectomy (larger dissections have a higher risk; also the intervention for recurrent goitre and second intervention for post-operatory bleeding increase the risk of hypocalcemia; while Basedow disease is probably at higher risk than multinodular goitre among benign conditions) and the duration of procedure. Pre-operatory low calcium, parathormon (PTH), 25-hydroxivitamin D increases the risk. The calcium drop rate matters as well: a decrease of 1 $\mathrm{mg} / \mathrm{dL}$ calcium over 12 hours after surgery is independently correlated with the risk of symptomatic hypocalcemia. Early post-operatory PTH and calcium are best predictors for the need of oral calcium supplements. Routine post-operatory calcium and vitamin D supplementation statistically significant decreases the risk of developing transitory hypocalcemia and acute complications compare to calcium alone supplements or no supplements. In cases of hypoparathyroidism calcitriol is preferred.
\end{abstract}

Key words: thyroidectomy, calcium value, calcium supliments

\section{Introduction}

Thyoidectomy represents a widely used intervention since thyroid nodules detection is increasing; actually $50-70 \%$ of adult population might have a thyroid incidentaloma (1-3). Post-operative hypocalcemia is reported with a variable incidence of 1.2 up to $40 \%$ depending of series or trials (1-3). The underling parathyroid condition is usually a transitory hypoparathyroidism but permanent damage is registered in less than $3 \%$ of subjects (1-3). The initial thyroid condition seems less important in relationship to the risk of developing hypocalcemia: malign conditions display a higher risk while Basedow-Graves's disease is potentially more frequently involved than multinodular goitre regarding benign diseases $(2,3)$. However the surgical skills and the surgeon's approach is an important contributor to post-operative hypocalcemia (4).

The hypocalcemia is important in deciding the patient's discharge after thyroidectomy and also in influencing the others hospitalizations for low calcium levels associated with severe symptoms (5).

\section{Aim}

On this paper we focus on the levels of calcium after performing a thyroidectomy for different medical conditions and we also aim to analyze the need of calcium supplements after 
thyroid removal in relationship to PTH (parathormone) levels.

\section{Method}

This is a brief narrative review of literature using PubMed as tool of research. A number of 50 papers have been consulted and considered eligible as references data base for this paper considering the mentioned objective.

\section{General Data}

We organized the data starting from the indication of thyroidectomy and finally pointing out the practical aspects of postoperatory hypocalcemia.

\section{The Thyroidectomy Procedure}

The procedure of thyroidectomy varies from total to bilateral subtotal, unilateral subtotal, partial resection of a nodule, etc; robotic, minimally invasive video-assisted either conventional $(6,7)$. It is generally regarded a safe procedure which dramatically changed during decades up to the point of a very short hospitalization or with outpatients $(6,7)$. This particular aspect of short hospital stay requires an adequate patient's education including for complications like post-operatory hypocalcemia $(6,7)$.

The complications of thyroidectomy varies from hypocalcemia and unilateral recurrent laryngeal nerve lesions (less frequent) up to very rare conditions like bilateral recurrent nerve paralysis, injury of vocal folds, local hematoma, cysts, granuloma, haemorrhage, etc (8-10). Of course, iatrogenic hypothyroidism due to thyroid removal is seen in most of cases of total resection (8-10). The complications are classified by some as early (within first 3 months) and late; they may be transient or permanent (8-10). Except for hypothyroidism, the others are essentially considered to be related to surgeon's skills (8-11). Some complications are life threatening as severe hypocalcemia, bilateral vocal cords paralysis and cervical hematoma (9-12).

\section{The Indications of Thyroidectomy}

Thyroidectomy is relatively frequent intervention since it targets thyroid nodules. However not every nodule requires surgery and blood assays of thyroid function, antibodies and neuroendocrine marker calcitonin assessment in addition to thyroid ultrasound and fine needle aspiration represents a very efficient panel of tools in order to adequately select the cases who are referred to surgery $(13,14)$.

The indication of thyroidectomy is established in various diagnostics. Thyroid malignancies include differentiated thyroid cancer as papillary and follicular, poorly differentiated and anaplasic carcinoma (1517). Also, medullar thyroid cancer is derived not from follicular cell, but from C-parafollicular cell with calcitonin secretion (18). Rarely thyroid metastasis is found in thyroid while primary thyroid lymphoma is frequently associated with an autoimmune chronic Hashimoto thyroiditis background (19). Neither chronic thyroiditis or primary lymphoma have as first line approach surgery even in selected cases this is indicated (19). Single or multinodular goitre is removed if compressive symptoms are presented; also, in cases with hyperthyroidism (including Basedow-Graves disease regardless the goitre aspect at ultrasound) or in subjects with suspected nodules for a malignancy (20).

\section{Surgical Risk Factors for Hypocalcemia}

The most common risk factors of hypocalcemia after thyroidectomy have been widely analyzed (21,22). A study of 278 subjects found a percent of $27.3 \%$ positive for hypocalcemia and $15.1 \%$ for hypoparathyroidism (21). Based on this trial, the hypocalcemia differs with age, sex (females seems to have a higher risk), it is more frequent if lymph node dissection is associated to thyroid remove, it differs with type of thyroidectomy (as expected, larger dissections have a higher risk; also the intervention for recurrent goiter and second intervention for post-operatory bleeding increase the risk of hypocalcemia) and the duration of 
procedure and also if the PTH is low or lownormal pre-operatory the post-operative hypocalcemia is more frequent $(21,22)$.

One meta-analysis published in 2018 showed that particular technical aspects might be reflected in hypocalcemia risk (23). For instance, inferior thyroid artery ligation associates a higher risk of low calcium after thyroidectomy but of only transitory, not permanent type (23).

\section{The Post-operatory Levels of Calcium}

Post-operatory hypocalcemia has been pointed as the most frequent complication after thyroidectomy in daily practice. This complication, even it seems rather harmless at first, in fact it represents an important element which contributes to hospital delay and, especially for severe forms, and it impacts the quality of life up to the point of developing life threatening forms (24-27). The cause of hypocalcemia is related to parathyroid gland damage which may be either permanently (very rare) or transitory. And this aspect is caused by the devascularisation of parathyroid glands in addition to potential injury or dissection. Low levels of calcium may be registered post-operatory at biochemical level (by testing the total and ionic serum calcium) and also by signs and symptoms commonly known as tetany. The loop of hypocalcemia mechanism that includes low parathormone levels is not always presented (24-27). The rate of calcium drop after thyroidectomy is also important, not only the values themselves (24). A retrospective study published in 2019 showed that a decrease of $1 \mathrm{mg} / \mathrm{dL}$ calcium over 12 hours after surgery is independently correlated with the risk of symptomatic hypocalcemia (24).

In addition to this aspect, we also mention the prospective study of Reddy AC. et al. on 100 adult patients (mean age of 41 years, $68 \%$ of them had a benign thyroid condition, total thyroidectomy was performed in $88 \%$ of cases and additional lymph nodes resection was provided in $12 \%$ of subjects) (26). PTH was tested 20 minutes after thyroid gland was removed (26). The PTH assay cutoff of 9 $\mathrm{pg} / \mathrm{mL}$ had $92 \%$ sensitivity and $83 \%$ specificity to predict post-operatory hypocalcemia, meaning that a value of parathormone above this level is considered safe for avoiding a life threatening episode of hypocalcemia (26). Other authors found that PTH at one hour after thyroid resection during a partial/subtotal thyroidectomy procedure has a predictive power of $94.4 \%$, respective a specificity of $83.6 \%$ with a positive predictive value of $53 \%$, and a negative predictive value of $98.7 \%$ (27).

Moreover, a combination of PTH and calcium assay might be more accurate to indicate the need for calcium replacement, for instance a value of intact PTH one hour postoperatory of higher than $10 \mathrm{pg} / \mathrm{mL}$ and a total calcium level higher than $8.5 \mathrm{mg} / \mathrm{dL}$ makes calcium supplementation unnecessary (28). Alternatively, a combination of PTH 6 hours after thyroidecomy of less than $12.1 \mathrm{pg} / \mathrm{mL}$ and serum total calcium during the first postoperatory day of less than $7.97 \mathrm{mg} / \mathrm{dL}$ (a sensitivity of $93.9 \%$ and a specificity of $100 \%$ ) offers a total sensitivity and a specificity of $100 \%$ to predict hypocalcemia thus indicating the need of oral intervention as preventive replacement (29).

Low levels of pre-operatory calcium, 25hydrroxivitamin D and PTH also might be predictive for their post-operatory values (22). However, the routine pre-operatory PTH or screening of 25-hydroxivitamin $\mathrm{D}$ as the best tool of vitamin $\mathrm{D}$ metabolism is not typically recommended for every thyroid condition with normal baseline calcium levels (22). The only exception is related to medullary thyroid cancer which requires a screening for MEN (Multiple Endocrine Neoplasia) type 2 meaning checking for primary hyperparathyroidism and also for a pheocromocytoma in association to calcitonin assays $(30,31)$.

\section{The Prophylactic Use of Oral Calcium}

A study of Langner E. et al. published in 2017 aimed to assess the need for prophylactic calcium administered after total thyroidectomy as oral supplements in order to avoid signs and 
symptoms of low calcium levels. This is a prospective analysis of 47 subjects (approximately half of them had benign thyroid conditions) who were randomized to receive post-operatory: either 3 grams (g) of oral calcium since the first day after surgery was done until the sixth day, either no calcium. The assessments of ionic calcium were at least 5 and they followed the patient within the first 6 months after thyroid removal. The group without calcium supplements had statistical significant higher risk of developing hypocalcemia from a biochemical as well as from a clinical point of view without other parameters being different as those related to calcium metabolism, also having similar initial thyroid conditions as thyroidectomy indication. The authors encourage the use of prophylactic calcium after any procedure of thyroidectomy and also a general hypocalcemia preventive standard strategy is needed (32).

Another prospective randomized study conducted by Arer IM. et al. evaluated the surgery induced - hypocalcemia in addition to serum PTH values in 106 subjects $(83 \%$ females) who suffered total thyroidectomy (mostly for benign conditions). One group of patients $(50 \%)$ who received calcium supplements was compared to another group of individuals who were planned to be offered a Placebo protocol. PTH and blood calcium assays were registered during the first postoperative day and then for 7 more days. Hypocalcemia with clinical manifestations was detected in $1 \%$ versus $33.9 \%$ of patients ( $\mathrm{p}$-value $<0.05)$. All of these required oral calcium adjustments without a specific pattern of timing of hypocalcemia (33).

The authors concluded that post-operatory PTH levels at 12 , respective 24 hours can predict the risk of further developing hypocalcemia $(32,33)$. The observation that PTH has predictive values is marked by two practical aspects: one is represented by the associated costs of assaying a blood test marker as PTH and the other one is related to the controversies around the best time to assess it $(32,33)$.
The prophylactic use of calcium supplements might be a more cost-effective method than actually treating the symptomatic hypocalcemia $(32,33)$. Thus the routine use of calcium and vitamin D in early post-operatory period of time is recommended. This combination is useful for both transitory and permanent hypothyroidism (34).

\section{Surgical Induced Hypoparathyroidism}

Hypoparathyroidism is diagnosed based on the combination of low intact PTH and low calcium, and high phosphorus (35-37). Acute hypocalcemia is a potentially lethal condition (35-37). Chronic hypocalcemia is treated with oral calcium and vitamin D supplements while acute forms with intravenous calcium. Since PTH cannot sustain the final biochemical step of vitamin D activation (meaning the renal conversion of 25-hydroxivitamin D into 1,25dihidroxivitamin D or calcitriol) calcitriol (or active formulas of vitamin D) is preferred to cholecalciferol (35-37). Typically hypocalcemia is registered if PTH decreases more than $80 \%$ from its pre-operatory levels $(35,36)$. In case of under treatment quality of life is impaired in chronic hypocalcemia including the risk of calcifications of different types due to increase calcium-phosphate product $(35,36)$. Low postoperatory PTH is expected in bilateral thyroid approach, central neck dissections, large goitres and prior condition with hypovitaminosis D like malnutrition or malabsorbtion (37). The principals of best preventive management regarding post-operatory hypocalcemia include a good surgeon's experience, gentle intra-operatory manipulation of parathyroid glands vessels in order to conserve their blood supply and a good background vitamin D levels. A post-operative level of PTH of less than $15 \mathrm{pg} / \mathrm{mL}$ is correlated with the risk of an acute episode (37). Close follow-up of calcium levels is necessary after thyroidectomy especially in cases which already presented acute complications. Usually, as a preventive method the empiric routine use of calcium and vitamin $\mathrm{D}$ is recommended (35-37). The risk of overtreatment are hypercalciuria, hyper- 
calcemia, kidney stones, and cardiac risk in patients at risk (38). The review published in 2019 using a Cochrane risk of bias showed that routine calcium and vitamin $\mathrm{D}$ supplementation statistically significant decreases the risk of developing transitory hypocalcemia and acute complications compare to calcium alone supplements or no supplements but it has a minor role in permanent severe forms (39). Others authors consider that actually the prevention of hypocalcemia starts intraoperatory with meticulous manipulation of parathyroid glands and their vessels (40-42). A part from prevention, treatment of hypocalcemia is indicated in patients with symptoms, with a level of corrected calcium less than 7.5 $\mathrm{mg} / \mathrm{dL}$ and in acute forms when intravenous calcium is necessary (40-42). Permanent hypoparathyroidism requires lifelong followup $(43,44)$. Recently, daily PTH injections have been introduced in one 2 years study in order to reduce the necessary of calcium and vitamin D (45). Moreover, parathyroid hormone peptides have been approved in some countries for severe cases of hypoparathyroidism (46-48).

\section{Discussions}

Some aspects need to be mentioned regarding the relationship thyroidectomy - hypocalcemia. First, the high prevalence of thyroid nodules and their relatively easy detection in general population increased the number of thyroidectomies during the last decades so post-operative hypocalcemia might not be so rare (49). Second, there is still a matter of debate regarding some topics. For instance, which is the exact timing of post-operatory PTH assay in order to adequately identify the calcium supplementation necessary, if the PTH assessment is a cost-effective tool of hypocalcemia detection and which is the exact protocol of calcium and vitamin $\mathrm{D}$ supplements after surgery (50). Also it is important to properly educate the patients who are early discharged or they are outpatients after surgery regarding the acute tetany risk and the importance of long term follow-up of chronic hypocalcemia. One final observation is related to the high prevalence in general population of vitamin D deficiency (some consider it as pandemic) which is an independent contributor to hypocalcemia following thyroidectomy (51).

\section{Conclusion}

Hypocalcemia post-thyroidectomy represents a dynamic topic, yet incompletely solved and prophylactic calcium and vitamin D supplements seem the best approach until now. Further protocols based on quantifying the prognostic markers are necessary. Permanent hypoparathyroidism requires lifelong treatment and a concern related to acute life threatening episodes of hypocalcemia. The gentle manipulation of parathyroid glands and their vessels during thyroidectomy represents a key approach in order to prevent hypocalcemia.

\section{Funding: Not applicable}

\section{Availability of Data and Materials}

All data generated or analyzed during this study are included in this published article.

\section{Authors' Contributions}

All authors have contributed equally in writing, reading and approving the final manuscript.

\section{Ethics Approval and Consent to Participate Not applicable.}

Consent for publication: Not applicable

Competing interests: Not applicable.

\section{References}

1. Dionigi G, Bacuzzi A, Bertocchi V, Carrafiello G, Boni L, Rovera F, et al. Prospectives and surgical usefulness of perioperative parathyroid hormone assay in thyroid surgery. Expert Rev Med Devices. 2008;5(6):699-704.

2. Hallgrimsson $P$, Nordenström $E$, Bergenfelz $A$, Almquist $M$. Hypocalcaemia after total thyroidectomy for Graves' disease and for benign atoxic multinodular goitre. Langenbecks Arch Surg. 2012;397(7):1133-7.

3. Hughes OR, Scott-Coombes DM. Hypocalcaemia following thyroidectomy for treatment of Graves' disease: implications for 
patient management and cost-effectiveness. J Laryngol Otol. 2011; 125(8):849-52

4. Su A, Wang B, Gong Y, Gong R, Li Z, Zhu J. Risk factors of hypoparathyroidism following total thyroidectomy with central lymph node dissection. Medicine (Baltimore). 2017;96(39):e8162.

5. Stedman T, Chew P, Truran P, Lim CB, Balasubramanian SP Modification, validation and implementation of a protocol for postthyroidectomyhypocalcaemia. Ann R Coll Surg Engl. 2018;100(2): 135-139.

6. Feroci F, Rettori M, Borrelli A, Coppola A, Castagnoli A, Perigli G, et al. A systematic review and meta-analysis of total thyroidectomy versus bilateral subtotalthyroidectomy for Graves' disease. Surgery. 2014;155(3):529-40.

7. Cirocchi R, Trastulli S, Randolph J, Guarino S, Di Rocco G, Arezzo A et al. Total or near-total thyroidectomy versus subtotal thyroidectomy for multinodular non-toxic goitre in adults. Cochrane Database Syst Rev. 2015;(8):CD010370.

8. Christou N, Mathonnet M. Complications after total thyroidectomy. $J$ Visc Surg. 2013;150(4):249-56.

9. Fan C, Zhou X, Su G, Zhou Y, Su J, Luo M, et al. Risk factors for neck hematoma requiring surgical re-intervention after thyroidectomy: a systematic review and meta-analysis. BMC Surg. 2019;19(1):98.

10. Chahardahmasumi $E$, Salehidoost R, Amini M, Aminorroaya A, Rezvanian $\mathrm{H}$, Kachooei $\mathrm{A}$, et al. Assessment of the Early and Late Complication after Thyroidectomy. Adv Biomed Res. 2019;8:14.

11. Quimby AE, Wells ST, Hearn M, Javidnia H, Johnson-Obaseki S. Is there a group of patients at greater risk for hematoma following thyroidectomy? A systematic review and meta-analysis. Laryngoscope. 2017;127(6):1483-1490.

12. Minuto MN, Reina S, Monti E, Ansaldo GL, Varaldo E. Morbidity following thyroid surgery: acceptable rates and how to manage complicated patients. J Endocrinol Invest. 2019 May 23. doi: 10.1007/s40618-019-01064-z. [Epub ahead of print]

13. Dumitru N, Ghemigian A, Carsote M, Albu SE, Terzea D, Valea A Thyroid nodules after initial evaluation by primary health care practitioners: an ultrasound pictorial essay. Archives of the Balkan Medical Union. 2016;51(3):434-438

14. Haugen BR. 2015 American Thyroid Association Management Guidelines for Adult Patients with ThyroidNodules and Differentiated Thyroid Cancer: What is new and what has changed? Cancer. 2017; 123(3):372-381.

15. Poiana C, Carsote M, Ardeleanu C, Terzea D, Avramescu ET, Neamtu $M C$, et al. The value of the immunohistochemistry in a case of gastric neuroendocrine tumor and thyroid metastasis. Rom J Morphol Embryol. 2011;52(1):187-92.

16. Carling T, Udelsman R. Thyroid cancer. Annu Rev Med. 2014;65:12537.

17. Poiana C, Virtej I, Carsote M, Banceanu G, Sajin M, Stanescu B, et al. Virilising Sertoli-Leydig cell tumour associated with thyroid papillary carcinoma: case report and general considerations. Gynecol Endocrinol. 2010;26(8):617-22

18. Weber T. Medullary Thyroid Carcinoma: Why Is Specialization Mandatory? Visc Med. 2018;34(6):419-421.

19. Noureldine SI, Tufano RP. Association of Hashimoto's thyroiditis and thyroid cancer. Curr Opin Oncol. 2015;27(1):21-5.

20. Bartsch DK, Luster M, Buhr HJ, Lorenz D, Germer CT, Goretzki PE; German Society for General and Visceral Surgery. Indications for the Surgical Management of Benign Goiter in Adults. Dtsch Arztebl Int. 2018;115(1-02):1-7.

21. Arer IM, Kus M, Akkapulu N, Aytac HO, Yabanoglu H, Caliskan K, et al Prophylactic oral calcium supplementation therapy to prevent early post thyroidectomy hypocalcemia and evaluation of post-operative parathyroid hormone levels to detect hypocalcemia: A prospective randomized study. Int J Surg. 2017;38:9-14.

22. Edafe 0 , Mech CE, Balasubramanian SP. Calcium, vitamin D or recombinant parathyroid hormone for managing post-thyroidectomyhypoparathyroidism. Cochrane Database Syst Rev. 2019;5: CD012845.

23. Orloff LA, Wiseman SM, Bernet VJ, Fahey TJ 3rd, Shaha AR, Shindo $\mathrm{ML}$, et al. American Thyroid Association Statement on Postoperative Hypoparathyroidism: Diagnosis, Prevention, and Management in
Adults. Thyroid. 2018;28(7):830-841.

24. Wang YH, Bhandari A, Yang F, Zhang W, Xue LJ, Liu HG, et al. Risk factors for hypocalcemia and hypoparathyroidism following thyroidectomy: a retrospective Chinese population study. Cancer Manag Res. 2017;9:627-635.

25. Edafe O, Antakia R, Laskar N, Uttley L, Balasubramanian SP. Systematic review and meta-analysis of predictors of postthyroidectomy hypocalcaemia. Br J Surg. 2014;101(4):307-20.

26. Bae YJ, Schaab M, Kratzsch J. Calcitonin as Biomarker for the Medullary Thyroid Carcinoma. Recent Results Cancer Res. 2015; 204:117-37.

27. Rosario PW, Calsolari MR. Usefulness of Serum Calcitonin in Patients Without a Suspicious History of Medullary Thyroid Carcinoma and with Thyroid Nodules Without an Indication for Fine-Needle Aspiration or with Benign Cytology. Horm Metab Res. 2016;48(6):372-276.

28. Sanabria A, Kowalski LP, Tartaglia F. Inferior thyroid artery ligation increases hypocalcemia after thyroidectomy: A meta-analysis. Laryngoscope. 2018;128(2):534-541.

29. Langner E, Tincani AJ, Negro AD. Use of prophylactic oral calcium after total thyroidectomy: a prospective study. Arch Endocrinol Metab. 2017;61(5):447-454

30. Castro A, Oleaga A, Parente Arias P, Paja M, Gil Carcedo E, Álvarez Escolá C. Executive summary of the SEORL CCC-SEEN consensus statement on post-thyroidectomyhypoparathyroidism. Acta Otorrinolaringol Esp. 2019 Aug 4. pii: 001-6519(19)30092-5.

31. Castro A, Oleaga A, Parente Arias P, Paja M, Gil Carcedo E, Álvarez Escolá C. Executive summary of the SEORL CCC-SEEN consensus statement on post-thyroidectomyhypoparathyroidism. Endocrinol Diabetes Nutr. 2019;66(7):459-463.

32. Huang SM. Do we overtreat post-thyroidectomy hypocalcemia? World J Surg. 2012;36(7):1503-8

33. Xing T, Hu Y, Wang B, Zhu J. Role of oral calcium supplementation alone or with vitamin $D$ in preventing post-thyroidectomy hypocalcaemia: A meta-analysis. Medicine (Baltimore). 2019;98(8): e14455.

34. Bai B, Chen Z, Chen W. Risk factors and outcomes of incidental parathyroidectomy in thyroidectomy: A systematic review and metaanalysis. PLoS One. 2018;13(11):e0207088.

35. Kazaure HS, Sosa JA. Surgical Hypoparathyroidism. Endocrinol Metab Clin North Am. 2018;47(4):783-796.

36. Dedivitis RA, Aires FT, Cernea CR. Hypoparathyroidism after thyroidectomy: prevention, assessment and management. Curr Opin Otolaryngol Head Neck Surg. 2017;25(2):142-146.

37. Kakava K, Tournis S, Papadakis G, Karelas I, Stampouloglou P, Kassi E, et al. Postsurgical Hypoparathyroidism: A Systematic Review. In Vivo. $2016 ; 30(3): 171-9$

38. Coimbra C, Monteiro F, Oliveira P, Ribeiro L, de Almeida MG, Condé A Hypoparathyroidism following thyroidectomy: Predictive factors. Acta Otorrinolaringol Esp. 2017;68(2):106-111.

39. Palermo A, Santonati A, Tabacco G, Bosco D, Spada A, Pedone C, et al. PTH(1-34) for Surgical Hypoparathyroidism: A 2-Year Prospective, Open-Label Investigation of Efficacy and Quality of Life. J Clin Endocrinol Metab. 2018;103(1):271-280

40. Marcucci G, Brandi ML. A New Era for Chronic Management of Hypoparathyroidism: Parathyroid Hormone Peptides. Front Horm Res. 2019;51:165-171

41. Marcucci G, Della Pepa G, Brandi ML. Drug safety evaluation of parathyroid hormone for hypocalcemia in patients with hypoparathyroidism. Expert Opin Drug Saf. 2017;16(5):617-625.

42. Marcucci G, Della Pepa G, Brandi ML. Natpara for the treatment of hypoparathyroidism. Expert Opin Biol Ther. 2016;16(11):1417-1424.

43. Valderrabano $P$ Mclver B. Evaluation and Management of Indeterminate Thyroid Nodules: The Revolution of Risk Stratification Beyond Cytological Diagnosis. Cancer Control. 2017;24(5): 1073274817729231

44. White MG, James BC, Nocon C, Nagar S, Kaplan EL, Angelos P, et al. One-hour PTH after thyroidectomy predicts symptomatic hypocalcemia. J Surg Res. 2016;201(2):473-479.

45. Holick MF. The vitamin D deficiency pandemic: Approaches for diagnosis, treatment and prevention. Rev Endocr Metab Disord. 2017;18(2):153-165 